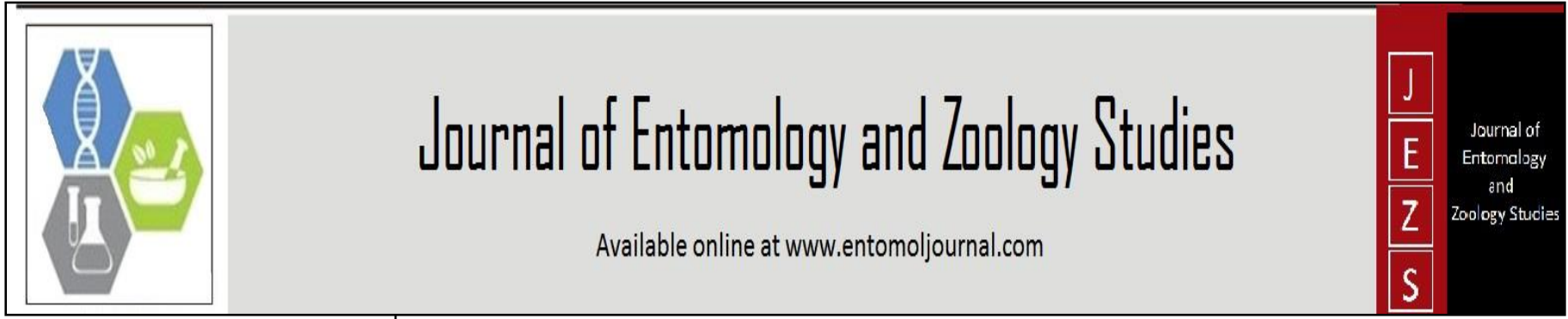

E-ISSN: 2320-7078

P-ISSN: 2349-6800

www.entomoljournal.com JEZS 2021; 9(2): 1353-1355 (C) $2021 \mathrm{JEZS}$

Received: 14-01-2021

Accepted: 20-02-2021

Prabaharan Vaiyapuri Assistant Professor, Department of Veterinary Gynaecology and Obstetrics, Veterinary College and Research Institute, TANUVAS, Tamil Nadu, India

Palanisamy Mahakrishnan

Professor and Head,

Department of Veterinary

Gynaecology and Obstetrics,

Veterinary College and Research Institute, TANUVAS, Tamil

Nadu, India

Satheshkumar Soundarapandian Professor and Head, Department of Veterinary Gynaecology and Obstetrics, Veterinary College and Research Institute,

TANUVAS, Tamil Nadu, India

Corresponding Author: Prabaharan Vaiyapuri Assistant Professor, Department of Veterinary Gynaecology and Obstetrics, Veterinary College and Research Institute,

TANUVAS, Tamil Nadu, India

\section{Efficacy of the progesterone impregnated intra - vaginal sponge on fertility in repeat breeding cows}

\section{Prabaharan Vaiyapuri, Palanisamy Mahakrishnan and Satheshkumar Soundarapandian}

DOI: https://doi.org/10.22271/j.ento.2021.v9.i2p.8628

\begin{abstract}
Supplementing exogenous Progesterone $\left(\mathrm{P}_{4}\right)$ during the early luteal phase shall increase the conception rate among the repeat-breeding cows. The present study was undertaken to compare the efficacy of the $\mathrm{P}_{4}$ impregnated intra-vaginal sponge (PIVS) which were used fresh and after storage, on fertility in repeat breeding cows. A total of 40 repeat breeding cows were selected and divided in to four groups randomly. Group I ( $n=10)$ : Freshly purchased PIVSs were used; Group II $(n=10)$ : PIVS were stored for 6 months after purchase and utilized; Group III $(\mathrm{n}=10)$ : PIVS were stored for 12 months after purchase and utilized; Group IV ( $\mathrm{n}=10)$ : No $\mathrm{P}_{4}$ supplementation(Control). The sponges were kept intravaginaly from Day 6-16 post insemination. Pregnancy diagnosis was performed 28-35 days after insemination. Blood samples were collected on Day 6 and Day 10 post insertion of the vaginal sponge for $\mathrm{P}_{4}$ hormone estimation. There was a significant decrease $(P<0.05)$ in $\mathrm{P}_{4}$ concentration on day 16 in both the pregnant and non pregnant animals of Group III when compared to Group I. There was no significant increase in $\mathrm{P}_{4}$ concentration in the control group in both pregnant and non-pregnant animals when compared between days 6 and 16. Even though higher fertility rates were observed in Group I, when compared to the other groups, it does not differ significantly at $P<0.05$ level. Based on the study, Progesterone impregnated intra-vaginal device may be used for increasing the conception rate in repeat breeding cows which are better to use within 6 months after production. Suitable adjuvant may be added to improve the keeping quality of the Progesterone impregnated intra-vaginal device for more than 6 months.
\end{abstract}

Keywords: progesterone impregnated intra-vaginal sponge, conception rate, repeat breeder, serum progesterone

\section{Introduction}

Reproductive efficiency is determined by the number of cows within a herd that become pregnant, give birth, and produce calves each year. The incidence of repeat breeding cows has been reported to be $15-20 \%{ }^{[1]}$. Causes of repeat breeding have been attributed to factors which are nutritional, hormonal, abnormalities in the gamete, delayed ovulation, inadequate luteal function, infection and managemental causes and compromises in artificial insemination (AI) procedures ${ }^{[2,3]}$.

Progesterone $\left(\mathrm{P}_{4}\right)$ is essential for orchestrating the histotrophic environment for the nourishment of the conceptus. Embryonic deaths are caused by genetic and environmental factors. Most embryonic deaths, especially due to hormonal disorders, are the result of luteal insufficiency ${ }^{[3]}$. For this reason, $\mathrm{P}_{4}$ or its analogues are supplemented to reduce embryonic losses before or after artificial insemination. Controlled breeding using progestagens such as Progesterone Releasing Intra-vaginal Device (PRID), Controlled Internal Drug Release Device (CIDR) or Norgestomet ear implants was effective in achieving good fertility in normally cycling dairy cattle ${ }^{[4]}$.

In repeat breeding cows, controlled breeding using a CIDR was found to be an effective tool to achieve a high pregnancy rate through a fine regulation of folliculogenesis ${ }^{[5]}$. Some researchers report an overall increase of $5 \%$ in pregnancy rates following $\mathrm{P}_{4}$ administration. $\mathrm{P}_{4}$ treatment for 6 days after artificial insemination can increase pregnancy rates $(10 \% \text { more })^{[6]}$. The concept of supplementing repeat-breeding cows with exogenous $\mathrm{P}_{4}$ during the early luteal phase could possibly increase conception rate per insemination was reported ${ }^{[7]}$. 
However, there are no reports on the efficacy of the $\mathrm{P}_{4}$ devices which were stored for variable periods. Hence, the present study was undertaken to compare the efficacy of the $\mathrm{P}_{4}$ impregnated intra-vaginal sponge (PIVS) which were used fresh and after storage, on fertility in repeat breeding cows.

\section{Materials and Methods}

Crossbred cows which were brought for insemination /infertility investigation to Gynaecology Unit of Veterinary Clinical Complex, Veterinary College and Research Institute, Orathanadu were utilized for the study. A total of 40 repeat breeding cows which were diagnosed as oestrum, free from uterine infections, without palpable genital tract abnormalities and having good body condition were selected for this study. All the selected animals were inseminated twice on subsequent days and divided into four groups randomly based on the application of PIVS insert. Group I $(n=10)$ : Freshly purchased PIVSs were used; Group II $(n=10)$ : PIVS were stored for 6 months after purchase and utilized; Group III $(n=10)$ : PIVS were stored for 12 months after purchase and utilized; Group IV ( $\mathrm{n}=10)$ : No $\mathrm{P}_{4}$ supplementation (Control).

The sponges were kept intravaginaly for 10 days from Day 616 post artificial insemination (Day 0- oestrum). Pregnancy diagnosis was performed 28-35 days after AI by trans-rectal ultrasound. Blood samples were collected on Day 6 and Day 10 post insertion of the vaginal sponge for $\mathrm{P}_{4}$ hormone estimation using a commercial Radioimmunoassay (RIA) progesterone kit (M/s Beckman Coulter). The data were compiled, expressed as a percent for better interpretation and analyzed statistically. The conception rates in the treatment cycle were compared between different groups by the Chisquare test. The data on serum profile was analyzed by using completely randomized design ${ }^{[8]}$.

\section{Results and Discussion}

The conception rates in repeat breeding cows treated with PVIS are presented in Figure 1. The conception rates in Group-I, II, III and IV were observed to be 60.00, 50.00, 40.00 and $30.00 \%$, respectively. The conception rate was higher in group-I, followed by group-II and III and lowest in untreated control group-IV. The results were statistically nonsignificant, except between group-II and IV.

Exogenous $\mathrm{P}_{4}$ supplementation has been shown to improve conception rates in cows when administered early in pregnancy, of course not earlier than 3 days following insemination ${ }^{[5]}$. The results of conception rate revealed the first service conception rate was the highest in the progesterone sponge treated group while it was the lowest in the progesterone depot injected group ${ }^{[9]}$.
PRIDs inserted in repeat-breeder cows from day 14 to day 19 improved the pregnancy rate ${ }^{[10]}$. Controlled breeding using CIDR and PGF $2 \alpha$ in combination with post insemination CIDR therapy from day 5 to 13 or alone led to an increase in the plasma $\mathrm{P}_{4}$ concentration and thereby improves the conception rate in repeat breeder cows under field conditions ${ }^{[11]}$. The increase in the conception rate in repeat breeder cows supplemented with $\mathrm{P}_{4}$ post artificial insemination might be due to an improved uterine environment for embryo survival and development ${ }^{[12]}$. Endometrial secretions, essential for stimulating and mediating the changes in conceptus growth and differentiation throughout the early pregnancy were directed by the steroid environment generated by the ovary [13]. High $\mathrm{P}_{4}$ concentrations during early stages of pregnancy were related to advancement of embryonic development leading to an increased level of interferon $-\tau$ production and connected increase pregnancy rate ${ }^{[14]}$. The results of this study corroborated the previous state above in that progesterone supplementation during the crucial post insemination period improves the conception rate.

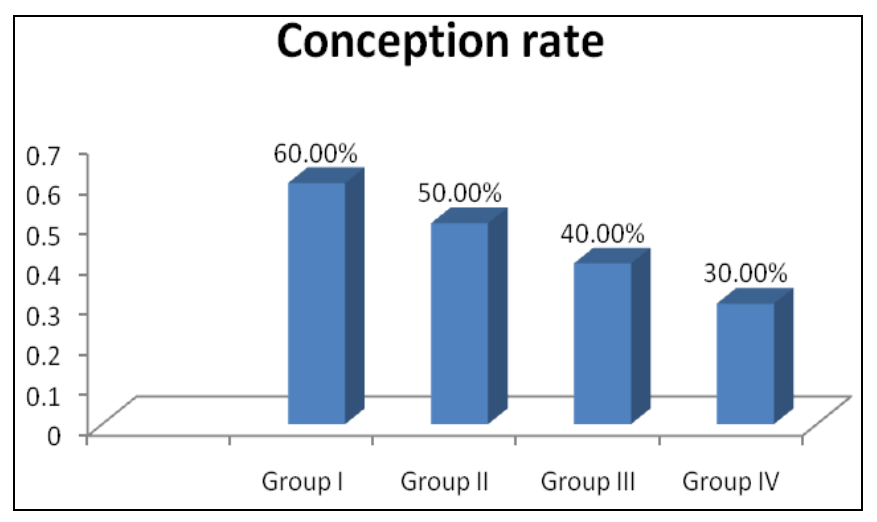

Fig 1: Conception rate in Repeat Breeding cows treated with post AI Progesterone impregnated vaginal sponge (different day of manufacture) and Untreated control group

In the present study, the mean plasma $\mathrm{P}_{4}$ levels on days 6 and 16 of the cycle in repeat breeder cows increased significantly $(P<0.01)$ as days progressed (Table 1$)$. There is a significant decrease $(P<0.05)$ in $\mathrm{P}_{4}$ concentration on Day 16 in both the pregnant and non pregnant animals of Group III when compared to Group I. There is no significant increase in $\mathrm{P}_{4}$ concentration in the control group in both pregnant and nonpregnant animals when compared between Day 6 and 16 . Even though higher conception rates were observed in Group I, when compared to the other groups, it does not differ significantly at $P<0.05$ level.

Table 1: Comparison of mean serum progesterone level in Repeat Breeding Cows on day 6 and 16 post insemination in different groups

\begin{tabular}{|c|c|c|c|c|c|c|c|c|}
\hline \multirow{2}{*}{ Pregnancy Status } & \multicolumn{4}{|c|}{ Day 6} & \multicolumn{4}{|c|}{ Day 16} \\
\hline & Group I & Group II & Group III & Group IV & Group I & Group II & Group III & Group IV \\
\hline Preg & $2.25 \pm 0.08^{\mathrm{bA}}$ & $2.24 \pm 0.22^{\mathrm{b}}$ & $1.34 \pm 0.03^{\mathrm{a}}$ & $1.48 \pm 0.02^{\mathrm{a}}$ & $6.53 \pm 0.10^{\mathrm{c}}$ & $5.30 \pm 0.15^{\mathrm{bc}}$ & $4.78 \pm 0.42^{\mathrm{b}}$ & $3.55 \pm 0.12^{\mathrm{aB}}$ \\
\hline Non-Pregnant & $1.38 \pm 0.04^{\mathrm{abB}}$ & $1.60 \pm 0.17^{\mathrm{b}}$ & $1.24 \pm 0.06^{\mathrm{a}}$ & $1.47 \pm 0.11^{\mathrm{ab}}$ & $5.48 \pm 0.08^{\mathrm{d}}$ & $5.13 \pm 0.07^{\mathrm{c}}$ & $4.69 \pm 0.10^{\mathrm{b}}$ & $3.93 \pm 0.04^{\mathrm{aA}}$ \\
\hline
\end{tabular}

Within columns means with different letters (A, B) differ significantly $(p<0.05)$ between pregnant and non-pregnant groups for the experimental group within the days.

Within rows means with different letters (a, b, c, d) differ significantly $(p<0.05)$ between the different experimental groups in pregnant and non-pregnant groups for days.

A low increase ${ }^{[15]}$ and moderate increase $(1 \mathrm{ng} / \mathrm{ml})$ above that in the control cows, has been reported previously in high milk producing cows treated with CIDR ${ }^{[16]}$ whereas a high increase $(4.2 \mathrm{ng} / \mathrm{ml}$ and $2.4 \mathrm{ng} / \mathrm{ml})$ in plasma $\mathrm{P}_{4}$ concentrations were achieved by CIDR treatment. No difference in progesterone levels of conceived and nonconceived buffaloes following CIDR treatment ${ }^{[17]}$. However, the exogenous $\mathrm{P}_{4}$ supplementation like intravaginal device during early luteal phase post insemination increased blood concentration of $\mathrm{P}_{4}$ and conception rate ${ }^{[18]}$. 
Administration of $\mathrm{P}_{4}$ has been revealed to increase endometrial protein secretion and growth factors concerned in the control of early embryo development ${ }^{[19]}$ and can improve both secretions of anti-luteolytic interferon-s and embryo survival ${ }^{[20]}$. The higher conception rate in animals by using $\mathrm{P}_{4}$ may be due to an improved uterine environment for embryo survival and development ${ }^{[11,12]}$.

\section{Conclusion}

The present study supports the hypothesis that supplemental progesterone in dairy cows from day 6 to day 16 post insemination will decrease pregnancy loss and increase conception rate. Progesterone impregnated intra-vaginal device may be used for increasing the conception rate in repeat breeding cows which are better to use within 6 months after production. A Suitable adjuvant may be added to improve the keeping quality of the Progesterone impregnated intra-vaginal device for more than 6 months.

\section{References}

1. Sreemannarayana O, Rao AVN. A comparative study of infertility in crossbred cows and buffaloes under village management. Indian Journal of Animal Reproduction 1997; 18:46-47.

2. Singh M, Pant HC. Factors responsible for AI failure in the field. Indian Veterinary. Journal 1998;75:1128- 1129.

3. Singh M, Pant HC. Factors associated with repeat breeding in Himachal Pradesh. Indian Veterinary. Journal 1999;76:522-523.

4. Shelton K, De Abru MFG, Hunter MG, Parkinson TJ, Lamming GE. Luteal inadequacy during the early luteal phase of subfertile cows. Journal of Reproduction and Fertiity 1990;90:10-15.

5. Robinson NA, Leslie KE, Walton JS. Effect of treatment with progesterone on pregnancy rate 193 and plasma concentrations of progesterone in Holstein cows. Journal of Dairy Science 1989;72:202-7.

6. Kim I, Suh G, Kim U, Kang H. A CIDR-based timed AI protocol can be effectively used for dairy cows with follicular cysts. Animal Reproduction Science 2006;95:206-213.

7. Devanathan TG, Pattabiraman SR, Asokan RC et al. Study on the efficacy of progesterone substitution therapy in repeat breeding cows. Indian Journal of Animal Reproduction 1999;20:79-80.

8. Snedecor GW, Cochran WG. Analysis of variance: the random effects model. Statistical Methods. Iowa State University Press, Ames, IA 1989, 237-252.

9. Jayachandran S, Muralidharan J. Estrus Induction and Conception Percentage in Anestrus Buffaloes treated with Progesterone. Shanlax International Journal of Veterinary Science 2015;3(1):12-19.

10. Villarroel A, Martino A, Bon Durant RH, Deletang F, Sischo WM. Effect of post insemination supplementation with PRID on pregnancy in repeat breeder Holstein cows. Theriogenology 2004;61(7):1513-1520.

11. Reshma A, Veerapandian C, Sathiamoorthy T, Arunmozhi N. Relationship of plasma progesterone levels following controlled internal drug release (CIDR) insertion and conception in repeat breeder cows. Journal of Entomology and Zoology Studies 2018;6(2):28512854.

12. Balakrishnan M, Bhaskar BV, Chinnaiya GP, Arora VK, Ramu A, Sharma TA. Progesterone supplementation and pregnancy rate receipt cross bred cattle. Indian Journal of Animal Reproduction 1994;15:94-97.

13. Wilmut I, Saleb DE, Ashworth CJ. Maternal and embryonic factors associated with prenatal loss. Fertility 1986;75:851-54.

14. Beltman ME, Lonergan P, Diskin MG, Roche JF, Crowe MA. Effect of progesterone supplementation in the first week post conception on embryo survival in beef heifers. Theriogenology 2009;71:1173-1179.

15. Chenault JR, Hornish RE, Anderson YC, Krabill LF, Boucher JF, Prough MJ. Concentrations of progesterone in milk of cows administered an intravaginal progesterone insert. Journal of Dairy Science 2003;86:2050-2060.

16. Sharma A, Jindal R, Singh N, Singh RV. Effect of progesterone supplementation on conception rate and hormonal profile in repeat breeding buffaloes. Indian Journal of Animal Science 2003;73(7):773-774.

17. Savalia KK, Dhami A, Hadiya KK, Patel KR, Sarvaiya NP. Influence of controlled breeding techniques on fertility and plasma progesterone, protein and cholesterol profile in true anestrus and repeat breeding buffaloes. Veterinary World 2014, 7(9).

18. Monteiro PLJ, Ribeiro ES, Maciel RP, Dias ALG, Sole E, Lima FS et al. Effects of supplemental progesterone after artificial insemination on expression of interferonstimulated genes and fertility in dairy cows. Journal Dairy Science 2014;97(8):4907-4921.

19. Garrett JE, Geisert RD, Zavy MT, Morgan GL. Evidence for maternal recognition of early conceptus growth and development in beef cattle. Journal of Reproduction and Fertility 1988;84:437-446.

20. Mann GE, Fray MD, Lamming GE. Effects of time of progesterone supplementation on embryo 100 development and interferon-tau production in the cow. Veterinary Journal 2006;171:500-3. 